\title{
The Impacts of Microaggressions on the Performance of Multiracial and Monoracial College Students
}

Jasmine S. Keith

Portland State University

Follow this and additional works at: https://pdxscholar.library.pdx.edu/mcnair

Part of the Gender, Race, Sexuality, and Ethnicity in Communication Commons, Social Psychology Commons, and the Sociology Commons Let us know how access to this document benefits you.

\section{Recommended Citation}

Keith, Jasmine S. (2016) "The Impacts of Microaggressions on the Performance of Multiracial and Monoracial College Students," PSU McNair Scholars Online Journal: Vol. 10: Iss. 1, Article 8.

https://doi.org/10.15760/mcnair.2016.6 
The Impacts of Microaggressions on the Performance of Multiracial and Monoracial College Students

\author{
By
}

Jasmine Keith

Faculty Mentor: Cece Ridder, PhD

Citation: Keith, J. The Impacts of Microaggressions on the Performance of Multiracial and Monoracial College Students. Portland State University McNair Scholars Online Journal, Vol. 10, Year 2016. 


\section{Abstract}

This study attempts to contribute to the research on how microaggressions affect performance of multiracial and monoracial college students in both social and academic realms. Data on microaggressions was collected through online surveys distributed via email to several hundred students. Participants consisted of students over the age of 18 at an urban institution in the Pacific Northwest. Bivariate logistical regression and axial coding were used to analyze participant responses. The first hypothesis for this study is that multiracial college students experience more microaggressions in social settings, while monoracial students experience more microaggressions in academic settings. The second hypothesis is that multiracial students experience privilege in academic settings, while monoracial students experience privilege in social settings. The final hypothesis is that the shade of skin tone of participants impacts their experiences with privilege, as well as their experience of microaggressions. Researchers found that multiracial students have a higher likelihood of experiencing microaggressions in a social setting and people with darker skin tones have a higher likelihood of experiencing microaggressions in an academic setting.

Keywords: multiracial, monoracial, campus setting, social setting, microaggressions 


\section{Introduction}

\section{Problem}

College students face many adversities that may impact their success, one of which is microaggressions. For the purpose of this study, microaggressions will be defined as "...brief and commonplace daily verbal, behavioral, or environmental indignities, whether intentional or unintentional, that communicate hostile, derogatory, or negative racial slights and insults..." (Sue, Capodilupo, Torino, \& Bucceri, 2007, pg. 271). While microaggressions are a relatively recent topic examined in the psychological community, it is growing in popularity in others as well, such as counseling and education. However, there is a lack of research and understanding on how microaggressions affect the success of both multiracial college students, people who identify as more than one race, and monoracial college students, people who identify as one race. Many factors can influence the types of microaggressions that a student may experience, as well as influence the impact on the student. These factors may include: gender, sex, age, and ability, although one of the most important factors is racial identity. Racial identity is the degree to which one identifies as a member of a particular racial group. For example, African Americans typically identify as "black" and see themselves as members of the black community. Identifying as a member of a community can be important to the development of one's self-esteem because intergenerational relationships are formed, allowing people to be influenced in their personal development of their own identity.

For many people, college is a time for self-exploration and is a place where identities develop. This is especially true for students of color or students with multiracial backgrounds because many multiracial students experience their race in a different ways than how monoracial students perceive their racial identity. Many monoracial people expect multiracial people to pick one race or ethnicity to claim. However, many multiracial people 
cannot pick one identity to claim because they feel that claiming only one identity is not being true to who they are and that being multiracial is a unique identity in itself. According to Ingram, Chaudhary, and Jones (2014), "how one identifies themselves and is identified by others can impact biracial students' college experience and the groups to which biracial students interact" (p.297). College can be a time for multiracial students to accept being multiracial as its own unique identity. Although for many students this is a positive thing, it also comes with a unique form of oppression that is typically subtler.

Past research has examined various topics involving multiracial college students and their relationships with microaggressions, which will be discussed in depth in the literature review section. They have found that multiracial identities impact interpersonal relationships. For example, multiracial students typically surround themselves with other multiracial people or they migrate between racial groups. Research has also found a connection between racism and a decrease in physical and mental health which can become present more prominently during the college years for students because that is often the age in which symptoms begin to show. They have also examined microaggressions in universities. For example, Harwood, Huntt, Mendenhall, and Lewis (2012) examined racial aggressions experienced by students of color in residence halls at a predominantly white institution, however they only focused on one portion of the university setting rather than examining other settings in which racial aggressions can take place. Researchers have also examined coping mechanisms of African American women who experienced microaggressions. Although most studies were qualitative, Nadal (2011) developed the Racial and Ethnic Microaggressions Scale (REMS), which was the first scale to measure microaggressions, and has been found to be an effective form of measurement.

Microaggressions are important to examine because they also can have a negative impact on the academic self-concept of college students. However, researchers tend to overlook microaggressions and instead focus more on overt racism, which is far less 
common in our current society and culture. This limited research on microaggressions leaves gaps in information. For example, past research has failed to examine microaggressions in regards to the performance of multiracial and monoracial college students across multiple fields. Additionally, researchers failed to make comparisons of various racial and ethnic groups which does not allow people to examine how each racial group is affected and how that may differ for each group.

\section{Research Question and Hypotheses}

This study examines how microaggressions affect the performance of multiracial and monoracial college students in social and academic realms to add to understanding of how interpersonal interactions impact self-esteem. This study examines how frequently microaggressions occur in academic and social settings, as well as who the perpetrators of these microaggressions are. Also, this study examines the regularity in which microaggressions occur and the reactions that people have to them. There are various hypotheses for this study. First, monoracial students experience more microaggressions in academic settings, while they experience privilege in social settings. Multiracial students experience more microaggressions in social settings, while they experience privilege in academic settings. Finally, the experience of microaggressions as well as the impact that they have on students will be influenced by participants' shade of skin tone.

\section{Literature Review}

A review of the literature suggests that microaggressions play a large role in the experience of students in college and that faculty should be more proactive in responding to microaggressions. In a recent study of college students of color at a Predominantly White University, Harwood, Huntt, Mendenall, and Lewis (2012) examined students' experiences in terms of racial microaggressions. Researchers conducted semi-structured interviews with open-ended questions about experiences related to discrimination, in which questions 
mostly came from Sue et al. (2007a), as Sue was one of the researchers to lay a foundation for studying microaggressions. Coding via line-by-line analysis was used to determine themes and categories from the data. Researchers found three different forms of microaggressions including "microassaults (verbal or nonverbal behavior aimed at hurting someone), microinsults (subtly demeaning snubs or dismissive looks and gestures that are often unconscious), and microindividualizations (minimizing or denying the racialized experiences of people of color)" (Harwood, 2012, p.164). There were two main manifestations of racial microaggressions: "individual-level racial microaggressions and environmental racial microaggressions" (Harwood, 2012, p.164). The main themes that occurred included: racial jokes and verbal comments, racial slurs written in shared spaces, and segregated spaces and unequal treatment.

In another study, researchers Harwood et al. (2012) examined the experiences of students of color in a predominantly white university through focus groups and interviews. They found that students of color experienced microaggressions from peers in the residence halls and university staff made students feel invalidated. Harwood et al. (2012) concluded that university housing departments should examine their educational mission and manage the perceptions of the department. University administration can be more involved in supporting diverse interactions by providing training for staff and students about racial microaggressions. There are several limitations with this study. This study only focused on one predominantly White institution in the Midwest and only one setting on campus. The authors called for future research that examines how students of color respond to microaggressions and how strategies vary for groups as well as individuals. This research only used qualitative methods and did not examine the range of student development.

Similar conclusions were found in a study by Boysen \& Fredonia (2012), which examined students' and teachers' perceptions of microaggressions, as well as how microaggressions could be managed. Boysen and Fredonia (2012) used surveys to collect 
data from participants, which measured perceptions of microaggressions by using various scales. Instructors' surveys also included a yes/no portion about whether they would respond to various scenarios. There were three different analyses completed: perceptions of microaggressions, responding to microaggressions, and gender as a possible confound. Analysis of variance (ANOVA) was used to analyze teachers' and students' perceptions of microaggressions in the classroom. Chi square analysis were used to determine the beliefs about appropriate or inappropriate responses to microaggressions. Logistic regression was used for the final analysis for exploring gender as a possible confounding variable. Three of the four hypotheses were confirmed. That is, instructors of diversity courses were more likely to respond, viewed microaggressions more negatively, and did not view ignoring the microaggression as an efficient response. The only hypothesis that was not confirmed, found the opposite to be true. Teachers' ratings of effectiveness were found to be significantly lower than students'. There were various limitations of this study. The samples were lacking racial diversity because participants were primarily form the same racial background so, there was no way to tell if the results would differ for students with an ethnic and racial minority background. Another limitation is the descriptions of the microaggressions and the measurement of effectiveness. The research would have been more effective if it had simulated scenarios with microaggressions so actual responses could be viewed. The study did not allow for an origin of differences in microaggression perceptions.

Hunt (2014) examined how student experience was impacted by microaggressions and how that affected their overall experience on campus. Hunt (2014) concluded that each student has a unique experience and that experience should be respected as well as embraced. This research was qualitative and used semi-structured interviews. The research found that students felt that most monoracial people on the college campus did not take the time to understand the experience of being multiracial. Due to time constraints, the 
researcher was limited in their number of participants and were unable to recruit from other universities, thus the findings may not be generalized outside of this sample. Hunt (2014) suggests that people get to know their own biases, provide resources specifically for multiracial students, as well as create inclusive spaces to better support multiracial students on college campuses.

\section{Methods}

\section{Participants}

Participants in this study consisted of students from a large urban university in the Pacific Northwest. Participants consisted of traditional freshmen to fifth year seniors and nontraditional students. Nontraditional students are students who either returned to college after taking a period of time away from college or students who are older and did not start college at 18 years old. Participants were sent an email inviting them to participate in the study. Faculty members were also forwarded the request for students to participate. There were a total of 66 respondents, 17 identified themselves as female and 11 identified themselves as male. Some participants declined providing information about their racial identity and gender identity as not all survey questions were required. The age of participants ranged from 18 to 64 . Ten participants identified as multiracial while 50 identified as monoracial. Out of those who responded, $61 \%$ stated that they were first generation students; neither parent has earned a four-year (Bachelor's) degree. Most students in this study had a grade point average of 3.1-3.5 on a 4.0 scale.

\section{Measures}

A survey was used to collect data and was made available in various formats. The survey consisted of both multiple choice questions, as well as open-ended questions. Multiple-choice questions were assigned numbers to allow researchers to code answers and open-ended questions were also coded for themes. Demographic questions were asked in 
beginning of the survey. Questions addressed experiences related to microaggressions in social and academic settings. For example, researchers asked about frequency of experiencing microaggressions, as well as participants' reactions to those experiences. A portion of Nadal's (2011) Racial and Ethnic Microaggressions Scale (REMS) was also used. All questions on the survey were voluntary, except whether or not participants agreed to the informed consent.

Table 1: Frequency Analysis Results

\begin{tabular}{|c|c|c|c|c|c|c|c|}
\hline Question & $\begin{array}{l}\text { I did not experience this } \\
\text { event in my time at PSU }\end{array}$ & $\begin{array}{l}\text { I experienced this } \\
\text { event } 1-3 \text { times }\end{array}$ & $\begin{array}{l}\text { I experienced this } \\
\text { event } 4-6 \text { times }\end{array}$ & $\begin{array}{l}\text { I experienced this } \\
\text { event } 7.9 \text { times }\end{array}$ & $\begin{array}{l}\text { I experienced this event } \\
10 \text { or more times }\end{array}$ & $\begin{array}{l}\text { Total } \\
\text { Responses }\end{array}$ & Mean \\
\hline $\begin{array}{l}\text { A faculty/staff or student was unfriendly or } \\
\text { unwelcoming toward me because of my race }\end{array}$ & 31 & 8 & 1 & 0 & 1 & 41 & 1.34 \\
\hline $\begin{array}{l}\text { My opinion was overlooked in a group } \\
\text { discussion because of my race }\end{array}$ & 27 & 10 & 1 & 1 & 2 & 41 & 1.56 \\
\hline $\begin{array}{l}\text { I was ignored at school or at work because of } \\
\text { my race }\end{array}$ & 29 & 7 & 2 & 0 & 2 & 40 & 1.48 \\
\hline $\begin{array}{l}\text { Someone assumed that my work would be } \\
\text { inferior to people of other racial groups }\end{array}$ & 26 & 6 & 4 & 2 & 2 & 40 & 1.7 \\
\hline $\begin{array}{l}\text { A faculty/staff or student treated me differently } \\
\text { than monoracial peers }\end{array}$ & 31 & 4 & 3 & 1 & 1 & 40 & 1.43 \\
\hline
\end{tabular}

\section{Procedure}

Participants received emails from researchers and forwarded emails from faculty asking them to voluntarily participate in an online survey. The link to the survey was posted on Facebook (personal accounts and accounts from various departments around campus) for students to complete and paper copies of the survey were available to students in various locations around campus. Surveys included an informed consent form, as well as the purpose of the study. Axial coding was used to analyze open-ended questions. Logistic regressions were used to test the hypotheses. Bivariate logistical regression in SPSS was used to analyze close-ended questions on the survey to test the hypotheses. 


\section{Results}

The bivariate logistical regression determined that racial identity, being monoracial or multiracial, did not determine whether students would experience microaggressions in an academic setting. That is, there was not a statistically significant relationship between racial identity and microaggressions in an academic setting. However, participants who indicated that they were multiracial had a greater likelihood of experiencing microaggressions in a social setting. That is, there is a significant relationship with microaggressions in a social setting $(p=.021)$ with odds ratio of 4.545 . There was not a statistically significant

Table 2: Bivariate Logistic Regression Predicting Microagressions in Social Settings

\begin{tabular}{llrrrr}
\hline Predictor & B & \multicolumn{1}{l}{ Wald } & P & Odds Ratio \\
\hline Racial Identity & & 1.51 & 5.32 & 0.021 & 4.54
\end{tabular}

Bivariate Logistic Regression Predicting Microagressions in Academic Settings

\begin{tabular}{llrrr}
\hline Predictor & B & Wald & P & Odds Ratio \\
\hline Skin Tone & 1.208 & 7.48 & 0.006 & 3.34
\end{tabular}

Note : Only significant results are included in this table.

relationship between skin tone and microaggressions in a social setting. Skin tone is statistically significant $(p=.006)$ in an academic setting with an odds ratio of 3.347 . People who have a darker skin tone have a higher likelihood of experiencing microaggressions on campus.

Most respondents reported that they had not experienced microaggressions from faculty or staff. When asked how many times respondents experienced a microaggression in an academic setting, $43.9 \%$ indicated "I did not experience this event," $28.1 \%$ indicated "I experienced this 1-3 times," $19.3 \%$ indicated "I experienced this $4-6$ times," $1.8 \%$ indicated "I experienced this 7-9 times," and 7.0\% indicated "I experienced this event 10 or

\begin{tabular}{|c|c|c|c|c|c|c|c|}
\hline Question & $\begin{array}{l}\text { I did not experience this } \\
\text { event in my time at PSU }\end{array}$ & $\begin{array}{c}\text { I experienced this } \\
\text { event 1-3 times }\end{array}$ & $\begin{array}{c}\text { I experienced this } \\
\text { event 4-6 times }\end{array}$ & $\begin{array}{c}\text { I experienced this } \\
\text { event } 7-9 \text { times }\end{array}$ & $\begin{array}{c}\text { I experienced this event } 10 \text { or } \\
\text { more times }\end{array}$ & Total Responses & Mean \\
\hline \multicolumn{8}{|c|}{$\begin{array}{l}\text { How many times have you experienced a } \\
\text { microaggression in an academic } \\
\text { (classroom, study space, etc.) setting at }\end{array}$} \\
\hline PSU? & $43.86 \%$ & $28.07 \%$ & $19.30 \%$ & $1.75 \%$ & $7.02 \%$ & $57.00 \%$ & $2.00 \%$ \\
\hline
\end{tabular}


more times." Fifty-eight percent of respondents felt that they had not experienced microaggressions in social settings. Forty-nine percent of participants expressed that they felt they did not experience privilege in social settings while $54 \%$ felt that they experienced privilege in academic settings.

Most respondents reported that they did not experience a microaggression in a social setting. When asked how many times they experienced a microaggression in a social setting, 40.4\% responded "I did not experience this event," 21.2\% stated "I experienced this event 1-3 times," 15.4\% responded "I experienced this event 4-6 times," $15.4 \%$ stated "I experienced this event 7-9 times, " and 7.7\% responded "I experienced this event 10 or more times." Sixty-three percent of respondents feel that if they have experienced microaggressions, they feel it is attributed to race. Fifty-three percent of respondents do not believe that microaggressions they experienced are attributed to skin tone.

\begin{tabular}{|c|c|c|c|c|c|c|c|}
\hline Question & $\begin{array}{l}\text { I did not experience this event } \\
\text { in my time at PSU }\end{array}$ & $\begin{array}{l}\text { I experienced this } \\
\text { event } 1-3 \text { times }\end{array}$ & $\begin{array}{l}\text { I experienced this } \\
\text { event 4-6 times }\end{array}$ & $\begin{array}{l}\text { I experienced this event } \\
7-9 \text { times }\end{array}$ & $\begin{array}{l}\text { I experienced this } \\
\text { event } 10 \text { or more } \\
\text { times }\end{array}$ & $\begin{array}{c}\text { Total } \\
\text { Responses }\end{array}$ & Mean \\
\hline $\begin{array}{c}\text { How many times have you } \\
\text { experienced a microaggression in a } \\
\text { social setting? }\end{array}$ & $40.38 \%$ & $21.15 \%$ & $15.38 \%$ & $15.38 \%$ & $7.69 \%$ & $52.00 \%$ & $2.29 \%$ \\
\hline
\end{tabular}

When asked, "How likely are you to respond to a microaggression in general?" $17 \%$ indicated "very unlikely," 12.2\% indicated "unlikely," 4.9\% stated "somewhat likely," 9.8\% were undecided, 24.4\% indicated "somewhat likely," and 22\% stated "likely." The majority $(63 \%)$ of participants identified that their racial identity does not differ from other people's perception of their identity. After experiencing microaggressions, most (60\%) of participants reported that they do not feel differently about themselves. The majority (79\%) of people also indicated that they do not go out of their way to dress or look a certain way to counteract a specific stereotype. 
The open-ended portion of the survey revealed that $49 \%$ of respondents experienced microaggressions, in general, related to race, gender, sexual orientation, socioeconomic status, and appearance while $51 \%$ stated that they do not experience microaggressions. Respondents indicated that microaggressions they experienced were mostly related to gender. The most common feelings respondents shared after experiencing microaggressions from peers as well as faculty and staff, were annoyance and anger. The most common example given of a microaggression experienced in an academic setting was having someone be surprised by the respondent's achievement as well as having someone make an assumption about a gender stereotype. The most common examples of microaggressions experienced in a social setting were:

- Gender stereotyping

- Implying gender stereotypes around queer identity

- $\quad$ Surprised by achievement

- Being asked, "what are you?"

- $\quad$ Being told how to identify

Participants feel that race and gender are the ways in which they experience privilege in both social and academic settings, for example being Caucasian and male.

\section{Discussion}

This pilot study tested three hypotheses about the performance of multiracial and monoracial students in social and academic settings. The first hypotheses stated that monoracial students experience more microaggressions in academic settings, while they experience privilege in social settings. The second hypothesis stated that multiracial students experience more microaggression in social settings while they experience privilege in academic settings. Both of these hypotheses were found to be partially true because there is not a statistically significant relationship between race and microaggressions in an 
academic setting, although racial identity is significant in a social setting. This result is not surprising due to the demographics of the university at which the study took place, which is a predominantly White university. Many monoracial people who identify as Caucasian do not experience microaggressions around racial identity because they are considered part of the majority. People often experience microaggressions around identities that give them minority status. For example, a white male might still experience microaggressions if they identify as homosexual as well because their identity as a queer person is of minority status. Fifty-four percent of respondents indicated that they experience privilege in an academic setting while $49 \%$ indicated that they experience privilege in a social setting, although it is unclear which racial groups respondents identify as. Students may have reported experiencing privilege in academic settings because they are all college students and there is privilege associated with being able to attend a college or university. The last hypothesis stated that the experience of microaggressions as well as the impact they have on students would be influenced by the shade of skin tone that participants have. This hypothesis was found partially true as well because skin tone does not have a statistically significant relationship with microaggressions in a social setting, however is significant in an academic setting. Microaggressions, privilege, and performance are difficult topics to measure and instruments should be examined further in future research. The general trend in the data shows that students at this urban university in the Pacific Northwest are experiencing microaggressions, however the majority of microaggressions experienced are related to other identities than race. The trend of the data makes sense when considering that the majority of participants were monoracial, specifically white, and identified as female.

This study does have limitations, although it offers a unique perspective on microaggressions in social and academic settings. The most important limitation is a lack of diversity in this sample because only one predominantly white institution in one part of the 
country was examined. The results of this study may not be able to accurately represent the experience of multiracial and monoracial students across the United States without looking at universities in other geographical locations. The hypotheses may have been proven true if this research was conducted at a more diverse campus, such as a historically black college or university. Another limitation was the amount of participants $(n=66)$. This small sample limited the types of analysis that could be done. A larger sample could give an accurate representation of the population. Future research should include a more diverse and larger sample to gain a better understanding of microaggressions across various racial identities. Also, future research should include multiple universities in different geographical locations to examine whether the experience of microaggressions differs based upon environments, cultures, etc.

Another important limitation of this study is that it primarily relied on self-reporting, which can allow for responder bias. Self-reporting can also be problematic specifically in relation to microaggressions because many people do not know the term. People may be experiencing microaggressions without having the terminology to describe what they are experiencing. People may not be able to think of a time in which they experienced a microaggression because microaggressions are subtle. Also, a limitation of this study is that it examined a university setting, which only allowed researchers to examine college students. Future research could examine adults in a workplace setting because the average adult spends a significant amount of their time in the workplace. This research did not have a second coder to account for researcher bias. Another important limitation of this study is that researchers were unable to carry out a mixed methods procedure as they originally intended to. Researchers were planning to include interviews because most past research has been qualitative, however there were not enough multiracial respondents willing to participate in interviews. Future research should include mixed methodology because it would increase the external validity of the project, which would make it more generalizable 
to other college campuses. Mixed methodology also allows researchers to gain a better understanding of participant experiences because participants are not limited by the structure of the survey. Despite all the limitations, this study yielded several interesting findings.

\section{Conclusion}

In summary, this study describes how microaggressions affect the performance of multiracial and monoracial college students on an urban campus. The majority of students in this sample experience microaggressions in relation to identities other than race, such as age, gender, sexual orientation, ability, etc. This study offers a foundation for research examining microaggressions in various settings. Although, the hope is that this study brings awareness to microaggressions, as they are a newly examined topic in psychology because microaggressions are still a form of racism, although they are subtle. Many people feel that racism is no longer an issue in today's society because it is less overt. However, it is still an issue that needs to be addressed by informing people that microaggressions exist, which can lead to cultural competency training for staff and students, as well as creating multiracial specific resources for students. 


\section{References}

Blume, A. W., Lovato, L. V., Thyken, B. N., \& Denny, N. (2012). The relationship of microaggressions with alcohol use and anxiety among ethnic minority college students in a historically white institution. Cultural Diversity and Ethnic Minority Psychology, 18(1), 45-54. http://dx.doi.org/10.1037/a0025457

Boysen, G. A., \& Fredonia, S. (2012). Teacher and student perceptions of micro aggressions in college classrooms. College Teaching, 60(3), 122-129. http://dx.doi.org/10.1080/87567555.2012.654831

Harwood, S. A., Huntt, M. B., Mendenhall, R., \& Lewis, J. A. (2012). Racial microaggressions in the residence halls: Experiences of students of color at a predominantly white university. Journal of Diversity in Higher Education, 5(3), 159-173. http://dx.doi.org/10.1037/a0028956

Helm, C. A. (2013). Relationship between racial microaggression and psychological wellbeing of african american college students (Doctoral dissertation). Retrieved from ProQuest Newspapers, Platinum Periodicals, Reference database.

Hunt, B. (2014, August 1). Who are you? Multiracial Students and microaggressions on college campuses. Retrieved July 27, 2015, from NASPA Student Affairs Administrators in Higher Education website: https://www.naspa.org/constituentgroups/posts/who-are-you-multiracial-students-and-microaggressions-on-collegecampuses

Hunt, B. L. (2014). Managing microaggressions: A study on the effect of microaggressions on multriracial college students. Education Administration: Theses, Dissertations, and Student Research, Spring(5).

Ingram, P., Chaudhary, A. K., \& Jones, W. T. (2014). How do biracial students interact with others on the college campus? College Student Journal, 48(2), 297-311. 
Johnson, A. B. (2006). Performance anxiety among african american college students. Journal of College Student Psychotherapy, 20(4), 31-38. http://dx.doi.org/10.1300/J035v20n04_04

Lewis, J. A., Mendenhall, R., Harwood, S. A., \& Huntt, M. B. (2013). Coping with gendered racial microaggressions among black women college students. Journal of African American Study, 17, 51-73. http://dx.doi.org/10.007/s12111-012-9219-0

Muenks, E. M. (2013). Awareness of racial microaggressions in the dominant culture (Doctoral dissertation). Retrieved from ProQuest Newspapers, Platinum Periodicals, Reference database.

Nadal, K. L. (2011). The racial and ethnic microaggressions scale (REMS): Construction, reliability, and validity. Journal of Counseling Psychology, 58(4), 470-480. http://dx.doi.org/10.1037/a0025193

Smith, T., \& Roberts, R.N. (1997). Expressions of prejudice among college students over three assessments. College Student Journal, 31(2), 235-237. Retrieved from http://web.b.ebscohost.com/ehost/detail/detail?sid=73c8dcc2-c0be-4630-b454e4a182361a0b\%40sessionmgr115\&vid=0\&hid=123\&bdata=JnNpdGU9ZWhvc3QtbGI $2 Z Q \% 3 d \% 3 d \# d b=\operatorname{tfh} \& A N=9708155394$

Sue, D. W., Capodilupo, C. M., Torino, G. C., \& Bucceri, J. M. (2007). Racial microaggressions in everyday life: Implications for clinical practice. American Psychologist, 62(4), 271-286. http://dx.doi.org/10.1037/0003-066X.62.4.271

Sydell, E. J., \& Nelson, E. S. (2000). Modern racism on campus: A survey of attitudes and perceptions. The Social Science Journal, 37(4), 627-635. Retrieved from http://ac.els-cdn.com/S0362331900001051/1-s2.0-S0362331900001051main.pdf?_tid=9c94d112-ee9d-11e4-92cf00000aacb361\&acdnat=1430332323_07f7ac730f293e07085077fcc08309f5 